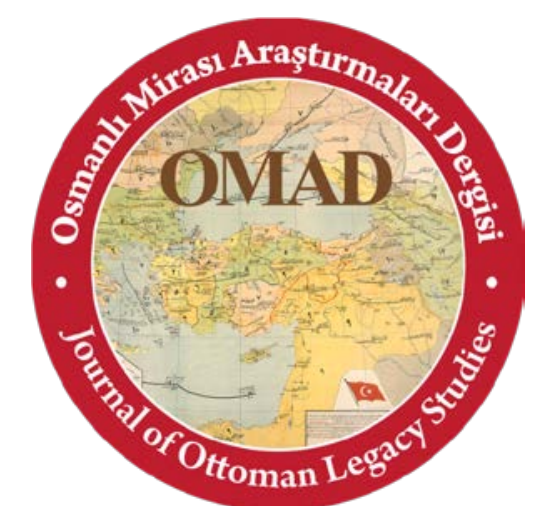

Osmanlı Mirası Araştırmaları Dergisi / Journal of Ottoman Legacy Studies

ISSN 2148-5704

www.osmanlimirasi.net

osmanlimirasi@gmail.com

Cilt 6, Sayı 15, Temmuz 2019/ Volume 6, Issue 15, July 2019

\author{
ALBANIAN CITIES IN SAMI FRASHERI'S ENCYCLOPEDIA “KAMUSU’L- \\ $\mathbf{A}^{\prime} \mathbf{L A M}^{\prime \prime}$ \\ Şemsettin Sami'nin Kamusu'l-a'lam'ında Arnavutluk Şehirleri \\ Makale Türü/Article Types : Araştırma Makalesi/Research Article \\ Geliş Tarihi/Received Date : 17.06.2019 \\ Kabul Tarihi/Accepted Date : 26.07.2019 \\ Sayfa/Pages : 309-315 \\ DOI Numaras1/DOI Number : http://dx.doi.org/10.17822/omad.2019.127
}

\title{
KUJTIM NURO
}

(Prof. Dr.), Member of Turkish and Ottoman Studies Association (USA), e-mail: kujtimnuro@hotmail.com, ORCID: https://orcid.org/0000-0002-1389-7449

\section{Atif/Citation}

Nuro, Kujtim, “Albanian Cities in Sami Frasheri's Encyclopedia "Kamusu'l-a'lam”, Osmanl Mirası Araştırmaları Dergisi [Journal of Ottoman Legacy Studies], 6/15, 2019, 309-315. 

Osmanlı Mirası Araştırmaları Dergisi (OMAD), Cilt 6, Sayı 15, Temmuz 2019.

Journal of Ottoman Legacy Studies (JOLS), Volume 6, Issue 15, July 2019.

ISSN: $2148-5704$

ALBANIAN CITIES IN SAMI FRASHERI'S ENCYCLOPEDIA “KAMUSU’L-A’LAM”* Şemsettin Sami'nin Kamusu'l-a'lam'inda Arnavutluk Şehirleri

\title{
KUJTIM NURO
}

\begin{abstract}
Sami Frasheri, historically known as Şemseddin Sami Bey, is one of the greatest scholars of Albanian and Turkish cultures. Although he lived a short life (1850 - 1904), his extensive works in the fields of linguistics, literature, history, geography, religion and more, have given great contributions not only to the history of two above-mentioned cultures, but also to other cultures and civilizations of the world. Sami Frasheri's works are written in either Turkish or Albanian and they account to more than 60 works. Among them, there are published and unpublished works such as, studies, novels, dictionaries, dramas, thesaurus, and translations. An important work in his collection is the encyclopedia titled, "Kamus-ul a'lam". An important section of this encyclopedia is composed of the data that Sami Frasheri wrote about the history and geography of Albanian cities, which were under the Ottoman administration. These cities were separated into four Albanian provinces, an administrative division that was made by the Sublime Porte (Babiali) in the year 1864. According to this division, Albanian cities were placed under the provinces of Ioannina, Kosova, Monastir and Shkodra. In this encyclopedia, Sami Frasheri described into details 68 cities.
\end{abstract}

Keywords: Albania cities, Sami Frasheri, Kamusu'l-a’lam

Öz: Tarihsel olarak Şemseddin Sami Bey olarak bilinen Sami Fraşeri, Arnavut ve Türk kültürlerinin en büyük âlimlerinden biridir. Kısa bir yaşam sürmesine rağmen (1850 - 1904), dilbilim, edebiyat, tarih, coğrafya, din ve daha birçok alanda yaptığı kapsamlı çalışmalar, sadece yukarıda belirtilen iki kültürün tarihine değil, aynı zamanda dünyanın diğer kültür ve medeniyetlerine de büyük katkılar sağlamıştır. Şemseddin Sami Bey’in eserleri Türkçe veya Arnavutça yazılmış ve 60’ın üzerinde eserden oluşmaktadır. Bunların arasında, romanlar, sözlükler, dramalar, eş anlamlılar ve çeviriler gibi yayımlanmış ve yayımlanmamış eserler vardır. Koleksiyonundaki önemli bir eser “Kamusu'l-a'lam” başlıklı ansiklopedidir. Bu ansiklopedinin önemli bir kısmı, Şemseddin Sami Bey'in, Osmanlı idaresindeki Arnavut şehirlerinin tarihi ve coğrafyası hakkında yazdığı verilerden oluşmaktadır. Bu şehirler, 1864 yılında Babıali tarafından yapılan idari bir bölüm olan dört Arnavut vilayetine ayrıldı. Bu bölüme göre, Arnavut şehirleri Yanya, Kosova, Manastır ve İşkodra vilayetlerine taksim edildi. Bu ansiklopedide, Şemsettin Sami Bey 68 şehri ayrıntılı olarak ele almıştır.

Anahtar Kelimeler: Arnavutluk şehirleri, Şemsettin Sami, Kamusu'l-a’lam

\section{The creation and publication of "Kamusu'l-a'lam”}

"Kamusu'l-a'lam" is an encyclopedic work, which contains numerous historical, geographical and bibliographical data. Sami Frasheri wrote this work by himself, in 6 volumes with a total of 4830 pages, for a period of nearly 10 years (1889-1898). This encyclopedia is the first encyclopedia written in Turkish, and it was published by the publishing house "Mihran in Istanbul. Sami Frasheri wrote the title of this work in Turkish "Kamusu'l-a'lam”, and also in French Universal Dictionnaire d'histoire et de Geographe. The author's name was included in full: Ch. Samy - Bey- Frachery. To write this encyclopedia, Sami Frasheri used multiple bibliographical sources from Arabic, Persian, Turkish, English, French, Italian authors etc. Besides these, he used the Ottoman yearbooks (salname) and official documents of the different

${ }^{*}$ Edited by Klejda Nuro. 
periods, some of which were covered by dust, and eaten by worms. The list of resources that Sami Frasheri used was particularly included by the "Mihran" publishing house. The director of the Library of University of Istanbul, Nurettin Kalkandelen (Tetova) had seen this list and attached it inside the first volume of "Kamusu'l-a'lam". ${ }^{1}$ During the preparation and publication of the encyclopedia, Sami Frasheri would write and edit proceeding volumes. ${ }^{2}$ The desire to write this work was there even long before, but he put it aside as he had not gathered the resources. ${ }^{3}$ From the encyclopedia that Sami Frasheri had read in European languages, he had noted that their countries and their prominent figures were largely accounted for, where as very little was written for the Oriental countries and their personalities. This was one of the reasons that he started to work on an extensive encyclopedia about the oriental countries, even though it was a hard task. ${ }^{4}$ There was no complete geography in the Turkish language and there were no maps of the territories of the Ottoman Empire. The works written in the languages of Europe were not a major source of data. Sami Frasheri worked on the preparation and completion of this work completing this work for nearly 10 years from 1889 to 1898 . Today, his encyclopedia has become one a key source for Ottoman studies and it can be found in almost all of the famous libraries in the world, public and university, including the library of the University of Toronto, in Canada. In Albania, this work is made well-known from partial translations completed by recognized Albanian famous orientalists such as, Zyber Bakiu ${ }^{5}$, Feti Mehdiu ${ }^{6}$, Mehdi Polisi ${ }^{7}$ etc.

\section{A brief overview of the contents of Kamusu'l-a'lam}

This work, with which holds great scientific values for both the Eastern and the Western world, contains extensive data regarding the history and geography of many different countries and their respective personalities. As he highlighted in the foreword "Ifade-i Meram", Sami Frasheri included ancestral origins of saints, tales about them, governor personalities, military commanders, vezirs, judges, halophytes, scholars of different fields of science and religion, erenler, sheiks, writers, poets, historians, chroniclers, travelers, data about the East and the West, names of well-known personalities from ancient times up to the new era, their biographies, works and publication descriptions, the continents of the globe, countries and states separated by boundaries, seas, straits, islands, mountains, rivers, lakes, names of villages which eventually turned into cities, their lengths and widths, historical and natural events, main products that were exported and imported, the alphabets that were used, historical and geographical works of Arab, Turkish, and Persian scholars etc.

\section{Albanian cities under the Ottoman Administration}

A considerable section of this encyclopedia is composed of the data that Sami Frasheri wrote about the history and geography of Albanian cities, which were under the Ottoman administration. These cities were separated into four Albanian provinces, an administrative division that was made by the Sublime Porte in the year 1864. According to this division, Albanian cities were placed under the provinces of Ioannina, Kosova, Monastir and Shkodra. In the encyclopedia, Sami Frasheri described 68 cities: Ajdonat, Akova, Alasonja, Berat, Bilisht, Delvina, Debre -I Bala, Debre-I Zir, Dodona, Durres, Elbasan, Filat, Gostivar, Gucia, Plava, Gjakova, Gjilan, Gjirokastra, HorpishtE, Ioannina, Kavaje, Kercovae, Kretove, Kruje,

\footnotetext{
${ }^{1}$ Agah Sirri Levend: Şemsettin Sami, Ankara, Turk Dil Kurumu Yayinlari, 1969, p. 84.

${ }^{2}$ Ibida.

${ }^{3}$ Şemsettin Sami, Kamusu'l-a’lam Istanbul, “ Mihran Matba’asi”, 1889, Vol. I.

${ }^{4}$ Ibid.

${ }^{5}$ Sami Frasheri: Shqiperia dhe Shiptaret (Albania and Albanians), Translated from original by Zyber Bakiu, Dajti 2000, Tirane, 2002.

${ }^{6}$ Kamus al a'lam (Enciklopedia- pjese te zgjedhura- the selected parts), Vepra 7, Translated: Feti Mediu, Rilindja, Prishtine, 1984.

${ }^{7}$ Sami Frasheri: Personalitetet shqiptare (Albanian Personalities) ne Kamus al a'lam, Vepra 9, Zgjodhi, perktheu dhe shpjegoi(Selected, translated, and explained) Mehdi Polisi, Logos-A, Shkup, 1994.
} 
Kumanove, Leskovik, Lezhe, Loros, Manastir(Bitol), Mitrovice, Naselici, Ohri, Parge, Peje, Peklin, Permet, Plave, Podgorice, Prešheve, Preveze, Priepolje Prilep, Prishtine, Prizren, Radovishte, Resnje, Sarande, Serfixhe, Starove, Pogradec, Suli, Shkoder, Skopje, Shpuze, Shtip, Tashlixhe, Tepelene, Tetove, Targovishte, Tirane, Bar, Ulkin, Vlore, and Vulcitern.

Sami Frasheri divided the cities into three groups based on their population numbers. The first group of cities included cities with populations over 30,0000 inhabitants. This group consisted of the cities of Shkoder, Prizren, Manastir( Bitol) and Ioannina. Ioannina, according to the data recorded by Sami Frasheri, which was based on official registrations conducted by the Ottoman administration, had a population of 35,000 people ${ }^{8}$, Prizren had 38,000 inhabitants ${ }^{9}$, Shkodra had 37,000 ${ }^{10}$ inhabitants with 4500 houses, and Manastir had 31,347 inhabitants. ${ }^{11}$ These cities were more populated than other cities because they they were city centers of their respective provinces. The second group consisted of cities with populations between 10,000 30,000 inhabitants, and it included Peja, Gjakova, Prishtina, Skopje, Tetova, Dibra, Tirana, Elbasan, Berat, Ohri, Korca, Kosturi, Gjirokastra, and Preveza. In this group, Skopje had the largest population with 25,000 inhabitants and 4,000 homes. ${ }^{12}$ After Skopje came the city of Elbasan with 20,000 inhabitants ${ }^{13}$, the Greater Dibra with 20,000 inhabitants ${ }^{14}$, Prilep with 18,378 inhabitants ${ }^{15}$, Peja with 18,000 inhabitants ${ }^{16}$, Korca also with 18, 000 inhabitants ${ }^{17}$, Tirana with 17,000 inhabitants ${ }^{18}$, Ohri with 16,000 inhabitants $^{19}$, and Tetova with 15,000 inhabitants. ${ }^{20}$ The cities of this group were generally the centers of the sancaks, which comprised the provinces. The third group consisted of cities with populations between 300010,000 inhabitants. This group was the largest in number as it included most Albanian cities. In this group, Sami Frasheri outline cities such as, Lezhe, Guci, Plave, Mitrovice, Kumanove, Gostivar, Kuprili, Prilep, Resnje, Kruje, Durres, Vlore, Tepelene, Permet, Delvine, Konice, Filat, Ajdonat, Margellic and Parge. ${ }^{21}$ Sami Frasheri recorded that the total population of the four Albania provinces was 2,500,000 inhabitants, of whom 2,000,000 were Albanian and 500,000 were Vlachs, Bulgarians, Greeks and Gypsy. ${ }^{22}$ However, according to the data that he gave in the description of each city, there were also Serbian, Turkish, and Jewish people living there. The majority of the population in these cities were Muslim Albanians. The main languages used during daily communication were Albanian and Turkish, but other languages were also used such as, Vlach, Greek and Spanish. ${ }^{23}$ Spanish was mainly used by the Jewish residents, who had come from Spain.

\section{A short history of the creation and establishment of Albanian cites under the Ottoman Administration}

The above-mentioned Albanian cities laid in northern Albania, which is named Gegeria, and in the southern part of it, which is named Toskeri. The mark of the geographical separation between these two parts was the Shkumbin river. Sami Frasheri, having explored a large

\footnotetext{
${ }^{8}$ Şemsettin Sami: Kamusu'l-a’lam, Vol. V, p. 4788.

9 Şemsettin Sami, Kamusu'l-a'lam, Vol. II, p.1495.

${ }^{10}$ Şemsettin Sami, Kamusu'l-a'lam, Vol. II, p. 977.

${ }^{11}$ Şemsettin Sami, Kamusu'l-a'lam, Vol. II, p. 4437.

12 Şemsettin Sami, Kamusu'l-a'lam, Vol. II, p. 933.

13 Şemsettin Sami, Kamusu'l-a'lam, Vol, III, p. 1157.

${ }^{14}$ Şemsettin Sami, Kamusu'l-a'lam, Vol. III, p. 2117.

15 Şemsettin Sami, Kamusu'l-a'lam, Vol. II, p. 1500.

${ }^{16}$ Şemsettin Sami, Kamusu'l-a'lam, Vol. II, p. 1116.

17 Şemsettin Sami, Kamusu'l-a'lam, Vol. V, p..3919.

${ }^{18}$ Şemsettin Sami, Kamusu'l-a'lam, Vol. III, p. 1717.

${ }^{19}$ Şemsettin Sami, Kamusu'l-a'lam, Vol. II, p. 1066.

20 SemsettinSami, Kamusu'l-a'lam, Vol. V, p. 3556.

${ }^{21}$ Şemsettin Sami, Kamusu'l-a'lam, Vol. I. p.147.

22 Şemsettin Sami, Kamusu'l-a'lam, Vol. I, p. 149.

${ }^{23}$ Şemsettin Sami, Kamusu'l-a'lam, Vol. VI, 4437.
} 
number of bibliographic resources, besides the physical and geographical descriptions and their natural beauties, gave very interesting data regarding the history and creation of many Albanian cities since the ancient times up to the Ottoman invasion, and their administration by the Sublime Porte. A part of the cities that Sami Frasheri described, were created in the antique period, like Alasonja which Homer of "Iliad had named Oloson". ${ }^{24}$ Another ancient city is Dodona in the province of Ioannina, which became known to the shrine of Jupiter. Another old city was Butrint, known as "Butrinto", "Butrintum", which is located in front of Corfu. ${ }^{25}$ These cities, which had an economic growth before the Ottoman Empire, experienced an economic destruction after the Ottoman invasion. Sami Frasheri, for one part of the cities gives also the etymology of their names. For example, the name Preveza city is taken from the old town named "Berniqia" as founder of the King of Illyria, Pirro. ${ }^{26}$ The city, which separates Gegeri from Toskëri, can be detached Albanopolisi mentioned by Ptolemy and other ancient geographers. During the Roman period, here crossed the road "Ignatius" with a large circulation between Durres and Thessaloniki. ${ }^{27}$ The Berat city, whichis mentioned in Ottoman documents as Arnavud Beligradi because it was occupied by the Serbs ${ }^{28}$, had an early century tradition in preserving cultural heritage, despite the belief that records belonged. Sami Frasheri had made wide clarifications by etymological viewpoint about the city of Durres. The city, he outlines, is founded by the Illyrian King, named Epidamnusi. Later, the town grew and suffered major changes from Dirahiuesi and the descendents gave the name: Durrahium. When the Constantinople Empire started to weaken, the city was conquered by the Normans. Later it passed under the occupation of the Venetians and in 1502 year was conquered by Sultan Bayazid II and the Turkish people called with name Drac. ${ }^{29}$ Even the city of Ioannina, at the time of the fall of the Constantinople empire, was founded by Jani King and during the final occupation in the year 1432 by Sultan Murad II, passed under the administration of the Ottoman administration. Also, this cty and the province,for a long time was lead by Tpedenli Ali Pasha, who made numerous constructions. ${ }^{30}$ Albanian cities, which, had been under Venidik administration, as well as other cities, after their conquest by the Ottoman army passed under the administration of the Sublime Porte. The first Albanian cities, which were occupied by the Ottoman Empire have been the Manastir city $(1382)^{31}$, and the Shtip city, an old city, named Astibus (1382). ${ }^{32}$ The later cities which conquered by the Ottoman army are Durres $(1502)^{33}$, Shkodra (1506) etc.

Simultaneously with the establishment of the Ottoman administration in Albanian territories are created the new cities Among the new cities, which were created in this time, Sami Frasheri mentioned Manastir city, which was built after the conquest by the Ottoman army in 1382 year $^{34}$, the city of Korca, established by Koca Mirahor Iljaz Bey ${ }^{35}$ at the end of the XV century, the city of Tirana in 1614 year by Süleyman Bey ${ }^{36}$, etc. But, among all Albanian cities, which they passed under the Ottoman rules will take the appearance of Oriental cities like Kruja, Shkodra, Berat and Elbasan, Preveza, Prizren, Pristina. Sami Frsheri will emphasise that Skopje is the first city in Rumeli, who took the color of the Oriental culture ${ }^{37}$ He would write

\footnotetext{
${ }^{24}$ Şemsettin Sami, Kamusu'l-a'lam, Vol. I, p. 280.

25 Şemsettin Sami, Kamusu'l-a'lam, Vol. II, p. 1366.

${ }^{26}$ Şemsettin Sami, Kamusu'l-a'lam, Vol. II, p.1507.

${ }^{27}$ Şemsettin Sami, Kamusu'l-a'lam, Vol. II, p. 1157.

${ }^{28}$ Şemsettin Sami, Kamusu'l-a'lam, Vol. II, p. 1260.

29 Şemsettin Sami, Kamusu'l-a'lam, Vol. III, p. 2124

${ }^{30}$ Şemsettin Sami, Kamusu'l-a'lam, Vol. VI, p.4788.

${ }^{31}$ Şemsettin Sami, Kamusu'l-a'lam, Vol. VI, p. 4437.

32 Şemsettin Sami, Kamusu'l-a'lam, Vol. II, p. 972.

${ }^{33}$ Şemsettin Sami, Kamusu'l-a'lam, Vol. III, p. 2124.

${ }^{34}$ Şemsettin Sami, Kamusu'l-a'lam, Vol. VI, p. 4437.

${ }^{35}$ Şemsettin Sami, Kamusu'l-a'lam, Vol. V, p. 3919.

${ }^{36}$ Şemsettin Sami, Kamusu'l-a'lam, Vol. III, p.1717.

${ }^{37}$ Şemsettin Sami, Kamusu'l-a'lam, Vol. II, p. 933.
} 
that "in the seventh century of our era, after a great resistance for a very long time against the Slavs, who came from the Northeast, attacked these province and Skopje for a long time made their provincial capital. After the great battle of Kosovo in 1389, during the period of Sultan Bayezid, the city was conquered by Timurtash Pasha. Pasa Yegit, was responsible for the management of the city. He, with the order of Sultan brought many Muslim people from Anatolia and set them there. ${ }^{38}$ Skopje, before of the invasion of the Ottoman army, is named Skopye. The Turkish people, this name, with a slight change turned in Uskup. The evidence of Oreintal culture of this city, built on two hills, which are located on both sides of the Vardar river, Sami Frasheri will write below, are the mosques, madrassas, foundations, hammams, the mausoleums of many Muslim clerics, poets and saints built by Sultan Murad II and the other sultans, by Yahya Pasha, and Isak bey. All these show that Skopje city in the first Ottoman period has had a huge impact on the Sublime Porte and has been an wisdom place of the first instance Sami Frasheri, also, gives the detailed information about the Ulkin city, which after the losing the independence of Illyria, felt into the hands of Rome, and later under the rule of the Eastern Empire. After this Empire had been occupied by Venice, Hungary, and Serbia. Finally, in the 1568 year is occupied by the Ottoman army. This city, being located on the opposite side of the city of Bari in Italy, is called Anti Bari. ${ }^{39}$

\section{The crafts in Albanian cities}

Sami Frasheri, in the description of the Albanian cities, a special attention dedicated to their economic development. The Leading role during the Ottoman administration from the XVI -XIX century in the development of the city, played the corporate of craftsmanship. In Albanian cities, in this period, many types of crafts had continued their long tradition. Their number which is exercised in these cities reaches the number 150. Their perfection during the centuries had brought the increasing of the requests for the internal and external market. He made a classification of the cities by main handicrafts that they are distinguished in all of Albanian provinces. Among the cities, which are the most advanced, in this period, Sami Frasheri will emphasize the city of Ioannina, Prizren and Shkodra. These cities were distinguished for the large number of workshops for processing of the stuff, which was the occupation of women, especially in the production of national clothing. Highlanders, -he writes-, dress entirely with stuff, worked from women with the wool of their sheep and does not need to bring them from Europe. ${ }^{40}$ But, he will notice with regret that last times the reach people are wearing the clothes coming from Europe which are setting aside the mention great abilities. Also among, these cities, Sami Frsheri will separate them, according to the improvement of production of jewellery and leather. He cites Prizren and Gjakova cities for processing with great finesse of the iron, preparing of the scissors, of the very beautiful arms, and even of the new system of the weapons. The city of Elbasan produced the barrels of the rifles, which were liked by Albanians. ${ }^{41}$ The different types of the arms, like shoot, guns of the old system are produced in the Peja city. ${ }^{42}$ Peja city, also is known for producing of the national clothing with the gold thread and of the silver vessels. Whereas the city of Skopje had been known for producing leather. The leather workshops are existed, also, in the Ajdonat city. ${ }^{43}$ The city of Korca, Manastir and Prishtina were a leading place in the processing of the products as carpets, blankets, socks, woollen sweater etc. This last city and the city of Parga distinguished for production of a type of soap, which was not produced in other cities. ${ }^{44}$ In Preveza city, in the end of the XIX century were established in the late nineteenth century, the factory for the

\footnotetext{
${ }^{38}$ Ibid.

${ }^{39}$ Şemsettin Sami, Kamusu'l-a'lam, Vol. III, p. 1717.

${ }^{40}$ Şemsettin Sami, Kamusu'l-a'lam, Vol. I, p. 149.

${ }^{41}$ Şemsettin Sami, Kamusu'l-a'lam, Vol. II, p. 1157.

${ }^{42}$ Şemsettin Sami, Kamusu'l-a'lam, Vol. II, p. 1116.

${ }^{43}$ Şemsettin Sami, Kamusu'l-a'lam, Vol. I, p. 280.

${ }^{44}$ Şemsettin sami, Kamusu'l-a'lam, Vol. II, p. 1498.
} 
production of the soap and olive oil factory. ${ }^{45}$ Korca city, also had the flour factory, but the city of Leskovik was known for preparing and baking of the sausages and cookies with almonds, which had become popular and requested by the local population and abroad. ${ }^{46}$

\section{The Development of the trade}

Albanian cities, which from the ancient times had a tradition of commerce, which had effected in their development. Among the cities, which are distinguished in the organization of the trade from the ancient times, Sami Frasheri mentioned the cities like Butrint, Durres, Elbasan, Ulklin, Parga, Preveza, Vlora, and Shkodra. The increasing of the number and production of the handicrafts brought as the result the opening and increasing of the the number of shops and bezistans(bazaar) to sell their products to complete and satisfy the different demands of the population, inside and outside of the city. According to the data, presented by Sami Frasheri, Berat had 600 stores, Gjakova, Prizren and Skopje 1000 stores each of them, Shtip, 900, Dibra, 420, Korca, 757, Peja 550, Preseva and Prishtina from 500, Gjirokastra 336 etj. Also, in the cities, besides of the shops, another form of advertising and the sale of products had existed from handicrafts and farmers. In the city of Ajdonatit, in September 23 of each year, organized a big fair, which continued 5 days. ${ }^{47}$ The city of Gucia organised the fair in October of each year. ${ }^{48}$ The big fairs were also organized in Korca, Konice, Leskovik, Permet, etc. Preveza city, at the end of XIX century, besides the expansion of the internal market, Albanian cities began the extension of the trade with other countries. They increase the exporting of the different crafts,the products of the s leather, wool, silk, agricultural and livestock, cheese, honey, wax, etc. Besides the exports, these cities, also imported the different products, particularly the industrial ones, which were missing in the Albanian provinces. The city of the Durres, was one of the main Ports during the Ottoman Empire. ${ }^{49}$ Sami Frasher, expressed the opinion that this city in order to reach again the importance that has been before, the port have to open and to be connected to a railway that would link it through Monastery with Selanik and Istanbul. ${ }^{50}$ From the harbor of Durres city, are exported the food items to the Trieste city. Also, the harbor of Preveza city has been more movement and from this port become trading with the ports of Trieste and Corfu. Residents of the Ulkin city, their life was connected with the sea, from were, they sailed on all shores of the Mediterranean with $400-500$ ships. -500 anije. ${ }^{51}$ Another famous city, during this period is the Skodra city. ${ }^{52}$ Its private commercial firms as "Coba", "Suma", "Pema", etc. have developed awider trade with the countries of Europe and and wider Europe. From this city through Boyana river, which linked to the Adriatic Sea, it exported more products of silk, honey and wax. During the Ottoman period, had been known for the trade inside and outside of the country, was the Vlora City. ${ }^{53}$ In the southern port of this city, there is a fairly wide gulf, named Pasha Harbor, were can stay an entire fleet. The most important part of the trade that constitute this city's export was olive oil, corn and other cereals, butter, fish, which were going totally to Greece and to another countries of the world . The import product were coffee, sugar and other products of Europe, which were coming from Trieste and were sent through the port of Vlora to Albania East. The region of Vlora had produced approximately one million oke (Okka) ${ }^{54}$ olive oil per year. But from Saline, which was near the city, was produced a half a million oke of salt per year. Sailing ships that came here in a year exceeded the number 260 and a small ship by the Austrian company " Lloyd "was

\footnotetext{
45 Şemsettin Sami, Kamusu'l-a'lam, Vol. II, p. 1507.

46 Şemsettin Sami, Kamusu'l-a'lam, Vol. V, p. 3991.

47 Şemsettin Sami, Kamusu'l-a'lam, Vol. I, p. 280.

48 Şemsettin Sami, Kamusu'l-a'lam, Vol. V, p. 3306.

49 Şemsettin Sami, Kamusu'l-a'lam, Vol. III, p. 2124.

50 Ibid.

51 Şemsettin Sami, Kamusu'l-a'lam, Vol. II, p.1098.

52 Şemsettin Sami, Kamusu'l-a'lam, Vol. II, p. 977.

53 Şemsettin Sami, Kamusu'l-a'lam, Vol. I, p. 493.

541 okka= 1283 gr.
} 
coming twice a week. Sami Frasheri states his opinion that "If we dry marshes and by enlarging the city toward to the coast, thanks to the local and commerce importance, there is no doubt that within a short time, would become the first city of the Ottoman possessions in the Adriatic, because of the cold water and has a very good climate and incomparable water. There, some reach people had built their villas. In the export of fruits was known in this period the Parga city. The population of this city secured more profits from the export of oranges, lemons and olives. In this city, are produced in numerous quantities the fruit of Cyprus and constantly was required by the Jews population. ${ }^{55}$ In the development of trade within cities of one province, of the different provinces, and other countries of the Balkans and Europe, an important role played road and rail transport system, although they were not in proper conditions. One of the most popular and the oldest road, built in the Roman period, was the road "Egnatia", which in English means the "long" and erroneously is called "Egnatius". This road started from the city of Durres and finished in Thessaloniki. ${ }^{56}$ Some of its cobble-stoned streets still exist, but the road is no longer in using. The main street was another road that started from Thessaloniki and Grackaja, came in Bitol, Korca and passed through extended until Ioannina. The Ottoman Empire, for the provinces that were under its management as well as for military purposes began to build the railways. Their construction increased more development of trade between provinces and countries. Between of them we can mention the railway that linked Kosova with the port of Thessaloniki, railroads, which were going from Skopje to Serbia and railroad which was coming from Europe passing western side of Vardar and joined the railway of Thessaloniki, in south of this city. The place of Skopje, where are joined also, two railway lines, they had grown more the importance of this city.

Furthermore, Sami Frasheri also included important information about the architecture of these cities, but this topic will be the subject of another paper.

\section{Bibliograpy}

Kamus al a'lam (Enciklopedia- pjese te zgjedhura), Vepra 7, Perktheu: Feti Mediu, Prishtine, "Rilindja”, 1984.

Levend,Agah Sirri, Şemsettin Sami, Ankara, Turk Dil Kurumu Yayinlari, 1969.

Sami Frasheri, Personalitetet shqiptare ne Kamus al a’lam, Vepra 9, Zgjodhi, perktheu dhe shpjegoi Mehdi Polisi, Logos-A, Shkup, 1994.

Sami Frasheri, Shqiperia dhe Shiptaret, Perktheu nga origjinali Zyber Bakiu, Dajti 2000,Tirane, 2002.

Şemsettin Sami, Kamusu'l-a'lam, Istanbul, Mihran Matba'asi, 1889 - 1899, Vol. I - VI.

\footnotetext{
${ }^{55}$ Şemsettin Sami, Kamusu'l-a'lam, Vol. II, p. 1463.

${ }^{56}$ Şemsettin Sami, Kamusu'l-a'lam, Vol. I, p. 149.

${ }^{57}$ Şemsettin Sami, Kamusu'l-a'lam Vol. II, p. 937.
} 